\title{
Breeding of Black Soybean Line with $t i$ and le Allele
}

\author{
Sangwoo Choi ${ }^{1}$, Sungjin Han ${ }^{1}$, Mikyung Sung ${ }^{2}$, Jong Il Chung ${ }^{2}$ * \\ ${ }^{1}$ Division of Applied Life Science, Graduate School, Gyeongsang National University, Jinju 52828, Korea \\ ${ }^{2}$ Department of Agronomy, Research Institute of Life Science, Gyeongsang National University, Jinju 52828, Korea
}

\begin{abstract}
Soybean is an economically important leguminous seed crop for feed and food products that are rich in seed protein, oil and saccharides. Also, black soybean has been known as medicinal food. However, Kunitz trypsin inhibitor (KTI) and lectin proteins are a main antinutritional factor in mature black soybean seed. The genetic removal of the KTI and lectin proteins will improve the nutritional value of black soybean seed. The objective of this research was to develop a new black soybean lines with double recessive allele for both KTI and lectin protein. A total of 179 F2 seeds were obtained from the cross of 'Gaechuck\#1' (Le/Le, ti/ti genotype) and 'LE-16' (le/le, Ti/Ti genotype) parents. The segregation ratios for the presence or absence of KTI and lectin proteins in the $\mathrm{F}_{2}$ seed generation were well fitted to an expected 3:1 ratio. The segregation ratios of 9:3:3:1 (113 Ti_Le_:28 Ti_lele:30 titiLe_:8 titilele) between $T i$ gene and $L e$ gene in $\mathrm{F}_{2}$ seed generation were observed $\left(\chi^{2}=3.71, P=0.5-0.1\right)$. From eight $\mathrm{F}_{2}$ seeds with double recessive allele ( $t i / t i$, le/le genotype), one new strain (titilele, both KTI, and lectin protein free) was developed. New strain has black seed coat, black hilum and green cotyledon in mature seed and 100-seed weight was $19.5 \mathrm{~g}$. This strain will be helpful in breeding program for selecting black soybean line with lacking both KTI and lectin protein.
\end{abstract}

Keywords Kunitz trypsin inhibitor, Lectin, ti, le, Recessive allele, Soybean

\section{INTRODUCTION}

Soybean (Glycine $\max (L$.$) Merr.) is the main source of$ protein and oil for human and animal nutrition. From the ancient time, black soybean has been consumed in Korea, China, and Japan. Black soybean has been known as medicinal food because of the presence of its antioxidant compound, especially anthocyanins in their seed coat. Anthocyanins are abundant in the epidermis palisade layer of black soybean seed coats. Three main anthocyanins (cyanidin-3-glucoside, delphinidin-3-glucoside, and petunidin-3-glucoside) were characterized in black soybean seed coats (Taylor 1976; Choung et al. 2001). Previous reports have demonstrated the health-promoting benefits of anthocyanins, which include antioxidant effects, reduction in the risk of coronary heart disease, regulation of adhesion molecules, and protection from ischemia and reperfusion heart injury (Burns et al. 2000; Kim et al. 2006). In addition, it has been reported that the anthocyanins or their components affect hyperglycemia and insulin secretion in a diabetic animal model (Jayaprakasam et al. 2005; Sasaki et al. 2007). Also, several antinutritional factors present in raw mature black soybean seeds. Kunitz trypsin inhibitor (KTI) and lectin proteins of mature black soybean seed reduce the nutritional value.

KTI protein is a small and non-glycosylated protein containing 181 amino acid residues with $21.5 \mathrm{kDa}$. KTI protein was first isolated and crystallized from soybean seeds by Kunitz (1945). The KTI protein strongly inhibits trypsin, thus reducing food intake by diminishing digestion and absorption. In United States Department of Agriculture (USDA) germplasm collection, two soybean accessions (PI157440 and PI196168) have been identified which lacks KTI protein (Orf and Hymowitz 1979a). Five electrophoretic forms of KTI have been discovered. The genetic control of four forms, $T i^{\mathrm{a}}, T i^{\mathrm{b}}, T i^{\mathrm{c}}$, and $T i^{\mathrm{d}}$, has been reported as a codominant multiple allelic series at a single locus (Singh et al. 1969; Hymowitz and Hadley 1972; Orf

Received March 28, 2016; Revised April 16, 2016; Accepted April 25, 2016; Published May 31, 2016

*Corresponding author Jong Il Chung, jongil@gnu.ac.kr, Tel: +82-55-772-1872, Fax: +82-55-772-1879 
and Hymowitz 1979a). Orf and Hymowitz (1979a) also found out that the fifth form does not exhibit a soybean trypsin inhibitor-A2 band and is inherited as a recessive allele designated as ti. The Ti locus has been located on linkage group 9 in the classical linkage map of soybean (Hildebrand et al. 1980; Kiang 1987), which was integrated in linkage group A2 (chromosome 8) of the USDA/Iowa State University soybean molecular linkage map (Cregan et al. 1999).

Soybean lectin protein is a glycoprotein with a molecular weight of $120 \mathrm{kDa}$ with four similar subunits (Pull et al. 1978). The soybean lectin is able to link to carbohydrate chains found in glycoproteins and glycolipids and present a strong affinity for $\mathrm{N}$-acetyl-D-galactosamine and to a lower extent for D-galactose. This lectin-carbohydrate interaction will consequently result into a changed morphology of the intestinal epithelium, as well as a decrease in the digestion and absorption of nutrients (Schulze et al. 1995). The presence of seed lectin is controlled by a single dominant gene designated $L e$ and the homozygous recessive lele results in the lack of lectin (Orf et al. 1978). Ti and Le loci were segregated independently (Orf and Hymowitz 1979b; Moraes et al. 2006; Lee et al. 2008). Recently, a new soybean line with triple null recessive genotypes (ti/ti-le/le-p34/p34) was developed (Schmidt et al. 2015).

KTI and lectin proteins limit the utilization of raw soybeans as direct feed requiring a heating step to denature the activity and energy costs as well as altering the physical properties of the soybean proteins. Also excessive heat treatment may lower amino acid availability. The genetic elimination of these factors could be an alternative to the heat treatment. The objective of this research was to develop a new black soybean lines with double recessive allele for both KTI and lectin protein.

\section{MATERIALS AND METHODS}

\section{Breeding population}

Two parents were used to develop breeding population. 'Gaechuck\#1' parent has Le/Le genotype (lectin protein present) and ti/ti gene (KTI protein absent). 'LE-16' parent has le/le genotype (lectin protein absent) and $T i / T i$ genotype (KTI protein present). The $F_{1}$ seeds were obtained from the cross of 'Gaechuck\#1' and 'LE-16' parents. $F_{1}$ seeds were planted and $F_{1}$ hybridity was confirmed on morphological traits in the greenhouse. $\mathrm{F}_{2}$ seeds derived from $\mathrm{F}_{1}$ hybrid plants were harvested. All $\mathrm{F}_{2}$ seeds harvested were analyzed for segregation and selection for KTI and lectin proteins.

\section{Determination of Kunitz trypsin inhibitor protein by sodium dodecyl sulfate (SDS)-polyacrylamide gel electrophoresis (PAGE)}

Crude protein from the parents and individual F2 seed was extracted to determine the presence ('+') or absence (' - ') of KTI protein electrophoretically. A piece of cotyledon from the parents and individual $\mathrm{F}_{2}$ seed was removed and was incubated for 30 minutes (at room temperature) in $1 \mathrm{ml}$ Tris-HCl, $\mathrm{pH} \quad 8.0$, containing $1.56 \% \mathrm{v} / \mathrm{v} \quad \beta$-mercaptoethanol. After centrifugation, $50 \mu \mathrm{l}$ of the supernatant was added to an equivalent amount of $5 \mathrm{X}$ sample buffer $(10 \% \mathrm{w} / \mathrm{v}$ SDS, $50 \% \mathrm{v} / \mathrm{v}$ glycerol, $1.96 \% \mathrm{v} / \mathrm{v} \beta$-mercaptoethanol, $1 \mathrm{M}$ Tris-HCl, $\mathrm{pH}$ 6.8). The samples were boiled at $97^{\circ} \mathrm{C}$ for 5 minutes and then centrifuged. Two microliters of the supernatant was loaded on a $12 \%$ acrylamide SDS polyacrylamide gel electrophoresis (SDS-PAGE) medium gels in Owl Separation Systems Inc. (Model: P9DS; Portsmouth, NH, USA). Electrophoresis was performed at $120 \mathrm{~V}$ for 7 hours. Gels were stained overnight in an aqueous solution of $0.25 \mathrm{~g}$ Coomassie blue R250, 10\% acetic acid, and $45 \%$ methanol. The gels were then destained with destaining solution (5\% acetic acid, 14\% methanol) for several hours. A wide-range SDS-PAGE molecular mass standard (Sigma Marker ${ }^{\mathrm{TM}}$, product code: M4038; Sigma, St. Louis, MO, USA) containing the 21.5 $\mathrm{kDa}$ (for KTI protein) was used to aid recognition of samples lacking the KTI protein. $\chi^{2}$ analysis was used to test the segregation ratio for KTI protein.

\section{Determination of lectin protein by westem blot analysis}

Proteins of parent and each $\mathrm{F}_{2}$ seed were separated by $10 \%$ or $12 \%$ SDS-PAGE, and transferred onto Immobilon-P membrane (PVDF, Millipore). After blocking for 2 hours in TBS buffer (20 mM Tris [pH 7.5], $150 \mathrm{mM} \mathrm{NaCl}$, and 
$0.1 \%$ Tween 20) with 5\% nonfat dried milk (Carnation, Glendale, CA, USA) at room temperature, the membrane were incubated with lectin antibody for 1 hour. After washing in TBS buffer three times, the blot was incubated with a horseradish peroxidase conjugated secondary antibody, and the complex was visualized using an enhanced chemiluminescence kit (Amersham, Buckinghamshire, UK). The thickness of band was then determined visually. $\chi^{2}$ analysis was used to test the segregation ratio for lectin protein.

\section{Development of double recessive genotype and seed traits}

The $\mathrm{F}_{2}$ seeds with double null allele (ti/ti, le/le genotype) were planted to advance $F_{2}$ plant generation. $F_{2}$ plants were individually harvested. Random $\mathrm{F}_{3}$ seeds from each $\mathrm{F}_{2}$ plant harvested were used to confirm absence for both KTI and lectin proteins. $F_{3}$ seeds with double recessive genotype ( $t i / t i, l e / l e)$ were planted to $\mathrm{F}_{3}$ plant generation. One strain with a proper agronomic traits was selected. Seed coat color, hilum color, cotyledon color, and 100-seed weight $(\mathrm{g})$ were recorded on the $\mathrm{F}_{4}$ seeds harvested.

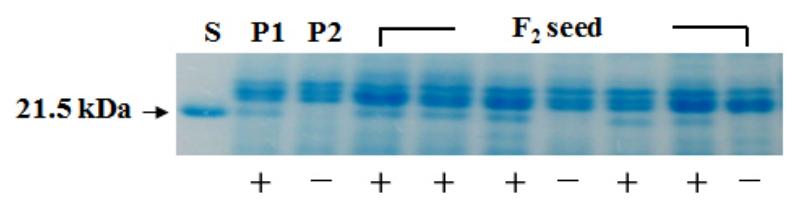

Fig. 1. Segregation of the Kunitz trypsin inhibitor (KTI) protein in the parents and $\mathrm{F}_{2}$ seeds. $\mathrm{S}$ : KTI protein, P1: 'LE-16', P2: 'Gaechuck\#1'. +, -: presence and absence of KTI protein, respectively.

Table 1. Segregation for the presence or absence of the Kunitz trypsin inhibitor (KTI) protein in $\mathrm{F}_{2}$ seed generation.

\begin{tabular}{ccccc}
\hline \hline \multirow{2}{*}{ KTI } & \multicolumn{2}{c}{ No. of $\mathrm{F}_{2}$ seed } & $\chi^{2}$ value & \\
\cline { 2 - 3 } protein & Observed & Expected & & \\
\cline { 2 - 3 } & $3: 1)$ & & \\
\hline+ & 141 & 134.25 & 1.36 & $0.5-0.1$ \\
- & 38 & 44.75 & 2.24 & $0.10-0.20$ \\
\hline
\end{tabular}

,+- : presence $(+)$ or absence $(-)$ of KTI protein.

\section{RESULTS}

A total of $179 \mathrm{~F}_{2}$ seeds were obtained from the crosses of 'Gaechuck\#1' and 'LE-16' parents. F $_{1}$ seeds produced KTI and lectin proteins. A part of the SDS-PAGE pattern for KTI protein that appeared in the parents and $F_{2}$ seed generation is shown in Fig. 1.

KTI protein of $21.5 \mathrm{kDa}$ was segregated in $\mathrm{F}_{2}$ seed generation. Segregation data for presence and absence of KTI protein are presented in Table 1.

Among $179 \mathrm{~F}_{2}$ seeds harvested, $141 \mathrm{~F}_{2}$ seeds showed $\mathrm{KTI}$ protein and $38 \mathrm{~F}_{2}$ seeds did not show KTI protein. The segregation ratio for the presence or absence of KTI protein in the $\mathrm{F}_{2}$ seed generation was well fitted to an expected 3:1 ratio $\left(\chi^{2}=1.36, P=0.5-0.01\right)$.

Segregation pattern for lectin protein that appeared in the parents and $\mathrm{F}_{2}$ seed generation is shown in Fig. 2.

Segregation data for presence and absence of lectin protein are presented in Table 2.

Among $179 \mathrm{~F}_{2}$ seeds, $143 \mathrm{~F}_{2}$ seeds showed lectin protein and $36 \mathrm{~F}_{2}$ seeds did not show lectin protein. The segregation ratio for the presence or absence of lectin protein in the $F_{2}$ seed generation was well fitted to an expected $3: 1$ ratio $\left(\chi^{2}=2.28, P=0.5-0.01\right)$.

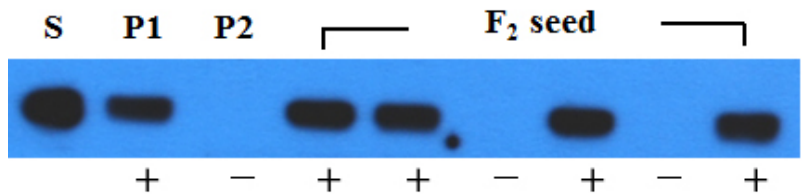

Fig. 2. Segregation of lectin protein in the parents and $F_{2}$ seeds. S: lectin protein, P1: 'Gaechuck\#1', P2: 'LE-16'. +, -: presence and absence of lectin protein, respectively.

Table 2. Segregation for the presence or absence of the lectin protein in $F_{2}$ seed generation.

\begin{tabular}{ccccc}
\hline \hline \multirow{2}{*}{$\begin{array}{c}\text { Lectin } \\
\text { protein }\end{array}$} & \multicolumn{2}{c}{ No. of $\mathrm{F}_{2}$ seed } & \multirow{2}{*}{$\begin{array}{c}\text { value } \\
(3: 1)\end{array}$} & $P$-value \\
\cline { 2 - 3 }+ & Observed & Expected & & \\
\hline- & 143 & 134.25 & 2.28 & $0.5-0.1$ \\
\hline
\end{tabular}

,+- : presence $(+)$ or absence $(-)$ of lectin protein. 
Table 3. Segregation for the presence or absence of Kunitz trypsin inhibitor (KTI) and lectin proteins in $\mathrm{F}_{2}$ seed generation.

\begin{tabular}{|c|c|c|c|c|c|}
\hline \multicolumn{2}{|c|}{ Seed protein } & \multicolumn{2}{|c|}{ Seed number } & \multirow{2}{*}{$\begin{array}{l}\chi^{2} \text { value } \\
(9: 3: 3: 1)\end{array}$} & \multirow{2}{*}{$P$-value } \\
\hline KTI & Lectin & Observed & Expected & & \\
\hline+ & + & 113 & 100.69 & \multirow{4}{*}{3.71} & \multirow{4}{*}{$0.5-0.1$} \\
\hline+ & - & 28 & 33.56 & & \\
\hline- & + & 30 & 33.56 & & \\
\hline - & - & 8 & 11.19 & & \\
\hline
\end{tabular}

+: presence, - : absence.

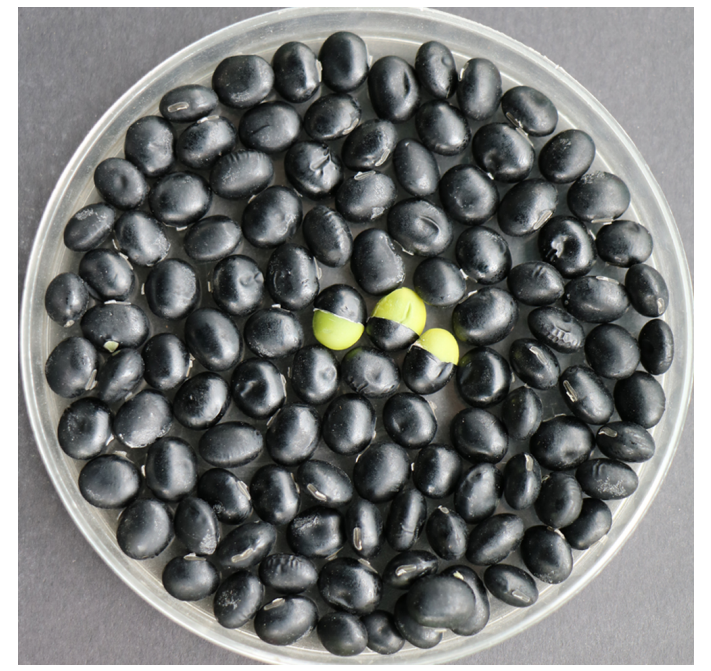

Fig. 3. Appearance of $F_{5}$ seed (double recessive allele, ti/ti, le/le genotype) with Kunitz trypsin inhibitor and lectin protein free, black seed coat and green cotyledon.

The segregation data for KTI and lectin proteins in the $\mathrm{F}_{2}$ seed generation are presented in Table 3. The segregation ratios of 9:3:3:1 (113 Ti_Le_:28 Ti_lele:30 titiLe_: 8 titilele) between $T i$ gene and $L e$ gene in $\mathrm{F}_{2}$ seed generation were observed $\left(\chi^{2}=3.71, P=0.5-0.1\right)$.

Eight $\mathrm{F}_{2}$ seeds with double recessive allele (ti/ti, le/le genotype) were planted and six seeds were germinated. Six $\mathrm{F}_{2}$ plants were individually harvested. Random $\mathrm{F}_{3}$ seeds from each $F_{2}$ plant were used to confirm absence for both $\mathrm{KTI}$ and lectin proteins. Among six $\mathrm{F}_{3}$ plant lines, one line with a proper agronomical traits were selected and were advanced to $\mathrm{F}_{4}$ plant generation. $\mathrm{F}_{5}$ seeds (tilti, le/le genotype) are shown in Fig. 3. Seed coat and hilum color were black. Cotyledon color in mature seed was green and 100 -seed weight was $19.5 \mathrm{~g}$.

\section{DISCUSSION}

Soybean seed contains nutritional components such as protein, oil, carbohydrate, isoflavone, saponin, and anthocyanin as well as several antinutrients responsible for reducing the nutritional value of unprocessed soybean. The antinutrients include trypsin inhibitor, and lectin proteins. KTI and lectin proteins limit the utilization of raw soybeans as direct feed requiring a heating step to denature the activity that imposes facility and energy costs as well as altering the physical properties of the soybean proteins. The genetic removal of KTI and lectin proteins could be an alternative to the heat treatment. A total of $179 \mathrm{~F}_{2}$ seeds were obtained to develop a new black soybean lines with double recessive allele for both KTI and lectin proteins from the crosses of 'Gaechuck\#1' and 'LE-16' parents. KTI protein in $F_{2}$ seed generation was segregated (Fig. 1, Table 1). The segregation ratio for the presence or absence of KTI protein in the $\mathrm{F}_{2}$ seed generation was well fitted to an expected 3:1 ratio $\left(\chi^{2}=1.36, P=0.5-0.01\right)$. This result shows that the absence of the KTI protein is controlled by a single recessive gene. Previous studies have shown that KTI protein is inherited as a single recessive allele (Orf and Hymowitz, 1979a; Kim et al. 2006; Eun et al. 2012). Also, lectin protein in $\mathrm{F}_{2}$ seed generation was segregated (Fig. 2, Table 2). The segregation ratio for the presence or absence of lectin protein in the $F_{2}$ seed generation was well fitted to an expected 3:1 ratio $\left(\chi^{2}=2.28, P=0.5-0.01\right)$. These results substantiate earlier reports that Le locus is inherited as a single gene (Orf and Hymowitz 1979b; Sung et al. 2013).

The segregation data for both KTI and lectin protein in the $F_{2}$ seed generation were presented in Table 3. The segregation ratios of 9:3:3:1 (113 Ti_Le_:28 Ti_lele: 
30 titiLe_:8 titilele) between Ti gene and Le gene in $\mathrm{F}_{2}$ seed generation were observed $\left(\chi^{2}=3.71, P=0.5-0.1\right)$. This data showed that $T i$ gene was inherited independently with the Le gene in soybean. These results substantiate earlier reports that $L e$ and $T i$ loci are segregate independently (Orf and Hymowitz 1979b; Moraes et al. 2006; Lee et al. 2008). Moraes et al. (2006) reported that $T i$ and Le loci were segregated independently using only $24 \mathrm{~F}_{2}$ individuals. Orf and Hymowitz (1979b) observed that $T i$ and $L e$ genes were not linked using $\mathrm{F}_{2}$ population with 96 individuals. Lee et al. (2008) were observed independent inheritance between $\mathrm{Ti}$ gene and $\mathrm{Le}$ gene from the $173 \mathrm{~F}_{2}$ seeds. From eight $\mathrm{F}_{2}$ seeds with double recessive allele (ti/ti, le/le genotype), one new strain was selected. Seed coat and hilum color of F5 seed (ti/ti, le/le genotype) strain was black and cotyledon color in mature seed was green (Fig. 3). Genotype of new strain for $T i$ and Le loci was titilele (both KTI and lectin protein free) and 100-seed weight was $19.5 \mathrm{~g}$. This strain will be helpful in breeding program for selecting black soybean line with lacking both KTI and lectin protein in mature seed.

\section{ACKNOWLEDGEMENTS}

This research was supported by Basic Science Research Program through the National Research Foundation of Korea (NRF) funded by the Ministry of Education (grant number: 2015059053).

\section{REFERENCES}

Burns J, Gardner PT, O’Neil J, Crawford S, Morecroft I, McPhail DB, et al. 2000. Relationship among antioxidant activity, vasodilation capacity and phenolic contents of red wine. J. Agric. Food Chem. 48: 220-230.

Choung MG, Baek IY, Kang ST, Han WY, Shin DC, Moon $\mathrm{HP}$, et al. 2001. Isolation and determination of anthocyanins in seed coats of black soybean (Glycine $\max ($ L.) Merr.). J. Agric. Food Chem. 49: 5848-5851.

Cregan PB, Jarvik T, Bush AL, Shoemaker RC, Lark KG, Kahler AL, et al. 1999. An integrated genetic linkage map of the soybean genome. Crop Sci. 39: 1464-1490.

Eun HH, Sung MK, Baek WJ, Shim SI, Kim MC, Chung JI. 2012. Inheritance of Kunitz trypsin inhibitor and P34 protein in soybean seed. Korean J. Crop Sci. 57: 78-82.

Hidebrand DF, Orf JH, Hymowitz T. 1980. Inheritance of an acid phosphatase and its linkage with the Kunitz trypsin inhibitor in seed protein of soybeans. Crop Sci. 20: 83-85.

Hymowitz T, Hadley HH. 1972. Inheritance of a trypsin inhibitor variant in seed protein of soybeans. Crop Sci. 12: 197-198.

Jayaprakasam B, Vareed SK, Olson LK, Nair MG. 2005. Insulin secretion by bioactive anthocyanins and anthocyanidins present in fruits. J. Agric. Food Chem. 53: 28-31.

Kiang YT. 1987. Mapping three protein loci on a soybean chromosome. Crop Sci. 27: 44-46.

Kim HJ, Tsoy I, Park JM, Chung JI, Shin SC, Chang KC. 2006. Anthocyanins from soybean seed coat inhibit the expression of TNF-alpha-induced genes associated with ischemia/reperfusion in endothelial cell by NF-kappaBependent pathway and reduce rat myocardial damages incurred by ischemia and reperfusion in vivo. FEBS Lett. 580: 1391-1397.

Kunitz M. 1945. Crystallization of a trypsin inhibitor from soybean. Science 101: 668-669.

Lee KJ, Park MS, Sung MK, Kim MS, Chung JI. 2008. Inheritance between $L e$ gene and $T i$ gene in soybean (Glycine max L.). Korean J. Breed Sci. 40: 97-100.

Moraes RMA, Soares TCB, Colombo LR, Salla MFS, Barros JGA, Piovesan ND, et al. 2006. Assisted selection by specific DNA markers for genetic elimination of the Kunitz trypsin inhibitor and lectin in soybean seeds. Euphytica 149: 221-226.

Orf JH, Hymowitz T, Pull SP, Pueppke SG. 1978. Inheritance of a soybean seed lectin. Crop Sci. 18: 899-900.

Orf JH, Hymowitz T. 1979a. Inheritance of the absence of the Kunitz trypsin inhibitor in seed protein of soybeans. Crop Sci. 19: 107-109.

Orf JH, Hymowitz T. 1979b. Soybean linkage test between Ti and Le seed proteins. Soybean Genet. Newsl. 6: 32.

Pull SP, Pueppke SG, Hymowitz H, Orf JH. 1978. Soybean lines lacking the 120,000-dalton seed lectin. Science 200: 1277-1279.

Sasaki R, Nishimura N, Hoshino H, Isa Y, Kadowaki M, Ichi T, et al. 2007. Cyanidin 3-glucoside ameliorates hyper- 
glycemia and insulin sensitivity due to downregulation of retinol binding protein 4 expression in diabetic mice. Biochem. Pharmacol. 74: 1619-1627.

Schulze H, Saini HS, Huisman J, Hessing M, Berg W, Verstegen MWA. 1995. Increased nitrogen secretion by inclusion of soya lectin in the diets of pigs. J. Sci. Food Agric. 69: 501-510.

Schmidt MA, Hymowitz T, Herman EM. 2015. Breeding and characterization of soybean triple null; a stack of recessive alleles of Kunitz Trypsin Inhibitor, Soybean Agglutinin, and P34 allergen nulls. Plant Breed. 134: 310-315.

Singh L, Wilson CM, Hadley HH. 1969. Genetic differences in soybean trypsin inhibitors separated by disc electrophoresis. Crop Sci. 9: 489-491.

Sung MK, Kim MH, Seo HJ, Chung JI. 2013. Inheritance of $d l m$ and $t i$ genes in soybean. Plant Breed. Biotech. 1: 9-13.

Taylor BH. 1976. Environmental and chemical evaluation of variations in hilum and seed coat colors in soybean [MS Thesis]. Fayetteville, AR, University of Arkansas. 